\title{
UJI PENGgAbUngAN PGPF DAN Pseudomonas putida STRAIN PF-20 DALAM PENGENDALIAN HAYATI PENYAKIT BUSUK LUNAK LIDAH BUAYA DI TANAH GAMBUT
}

\author{
Supriyanto $^{1}$, Achmadi Priyatmojo ${ }^{2} \&$ Triwidodo Arwiyanto² \\ ${ }^{1}$ Jurusan Budidaya Pertanian, Fakultas Pertanian, Universitas Tanjungpura \\ Jl. Imam Bonjol Pontianak 78124. E-mail: hayuponti@yahoo.co.id \\ ${ }^{2}$ Jurusan Perlindungan Tanaman, Fakultas Pertanian, Universitas Gadjah Mada \\ Jl. Flora 1 Bulaksumur Yogyakarta 55281
}

\begin{abstract}
PGPF and Pseudomonas putida Pf-20 combination test in the biological control of soft rot disease of aloe on peat land. Aloe (Aloe vera L. Webb) planted in West Borneo peat land is well known to have the best product quality in Indonesia. Bacterial soft rot is one of the constraints on aloe cultivation on peat land. Many methods have not given significant result for controlling this disease. The research objectives were to study the application of PGPF and its combination with Pseudomonas putida Pf-20 for controlling aloe bacterial soft rot on peat land. In vitro test showed that two isolates of PGPF tested had different respons when combining with P. putida Pf-20. The bacterial P. putida Pf-20 inhibit the growth of PGPF SNTH003 (Aspergillus sp.) as $20.14 \%$ on King's B and $7.48 \%$ on PDA, whereas SNTH001 (Penicillium sp.) as 62.4\% on King's B dan 34.39\% on PDA. Glass house trial showed that root dipping in P. putida Pf-20 suspension could not promote the growth of aloe, but could reduce the disease intensity. The single application of SNTH001 and SNTH003 isolates were able to increase the growth of aloe compare with its combination each of PGPF isolates with P. putida Pf-20. Single application of SNTH003, SNTH001 and P. putida Pf-20 was able to reduce the disease intensity of bacterial soft rot, but the capability decreased when each of PGPF combined with P. putida Pf-20. However combination between SNTH003 and P. putida Pf-20 increased that disease intensity. The lowest disease intensty (25\%) obtained by using SNTH001 isolate.
\end{abstract}

Key words: aloe, bacterial soft rot, peat land, PGPF, Pseudomonas putida Pf-20

\begin{abstract}
ABSTRAK
Uji Penggabungan PGPF dan Pseudomonas putida Strain Pf-20 dalam Pengendalian Hayati Penyakit Busuk Lunak Lidah Buaya di Tanah Gambut. Lidah buaya (Aloe vera L. Webb.) asal tanah gambut Kalimantan Barat dikenal mempunyai kualitas terbaik di Indonesia. Penyakit busuk lunak yang disebabkan oleh bakteri merupakan salah satu kendala dalam pengembangan tanaman lidah buaya di lahan gambut dan beberapa cara pengendalian yang telah dilakukan belum memberikan hasil nyata. Penelitian ini bertujuan untuk mengetahui pengaruh aplikasi Plant Growth Promoting Fungi (PGPF) dan penggabungannya dengan agensia hayati Pseudomonas putida strain Pf-20 untuk pengendalian penyakit busuk lunak lidah buaya di tanah gambut. Secara in vitro, kedua isolat menunjukkan respon berbeda ketika digabungkan dengan $P$. putida strain Pf-20 Aspergillus sp. terhambat sebesar 20,14\% pada medium King's B dan 7,48\% pada medium PDA. Sedang Penicillium sp. terhambat sebesar 62,4\% pada medium King's B dan 34,39\% pada medium PDA. Pada percobaan rumah kaca, pemberian isolat SNTH003 (Aspergillus sp.) dan SNTH001 (Penicillium sp.) secara tunggal mampu mengurangi intensitas penyakit, tetapi kemampuannya menurun ketika dilakukan penggabungan dengan P. putida strain Pf-20. Pemberian dua isolat tersebut secara tunggal juga mampu meningkatkan pertumbuhan lidah buaya lebih baik dibandingkan jika diaplikasikan bersama $P$. putida strain Pf-20. Pemberian P. putida strain Pf-20 dengan cara perendaman akar selama 15 menit dalam suspensi mampu mengurangi intensitas penyakit busuk lunak lidah buaya sebesar $40 \%$, tetapi tidak mampu memperbaiki pertumbuhan lidah buaya. Intensitas penyakit terendah diperoleh dari pengendalian dengan pemberian isolat SNTH001 (Penicillium sp.) yaitu sebesar $25 \%$.
\end{abstract}

Kata kunci: busuk lunak, lidah buaya, PGPF, Pseudomonas putida Strain Pf-20, tanah gambut 


\section{PENDAHULUAN}

Lidah buaya (Aloe vera L. Webb.) merupakan salah satu tanaman unggulan pada lahan gambut Provinsi Kalimantan Barat, khususnya di Kota Pontianak (Rianto \& Sarbino, 2004; Kusnandar et al., 2006). Lahan gambut di sekitar Kota Pontianak dan Kabupaten Pontianak sangat sesuai untuk pertumbuhan lidah buaya (Balai Pengkajian Bioteknologi BPPT \& Pemerintah Kota Pontianak, 2001), sehingga menghasilkan lidah buaya berkualitas prima, pelepah lebih panjang (60-70 $\mathrm{cm}$ ), berat mencapai $1,5 \mathrm{~kg}$ dan kandungan gelnya lebih banyak (Diperta Kalbar, 2001; Aisyah, 2005; Anonim, 2008).

Pengembangan lidah buaya di lahan gambut dihadapkan pada kendala berupa hambatan budidaya yang berhubungan dengan karakteristik tanah gambut yang kurang subur dan adanya penyakit busuk lunak yang disebabkan oleh bakteri (Rianto \& Sarbino, 2004; Suswati et al., 2005; Aminardi et al., 2006). Penyakit busuk lunak pada tanaman lidah buaya disebabkan oleh bakteri Erwinia chrysanthemi (sinonim Pectobacterium chrysanthemi) (Mandal \& Maiti, 2005; Charkowski, 2007). De Laat et al. (1994) melaporkan bahwa penyakit busuk lunak pada daun lidah buaya disebabkan oleh Erwinia chrysanthemi biovar 3. Berdasarkan wawancara dengan petani, kerugian karena penyakit busuk lunak dapat mencapai 25\%. Berbagai upaya pengendalian yang sudah dilakukan petani belum menunjukkan hasil memuaskan.

Mengingat gambut merupakan timbunan bahan organik dengan laju perombakan yang lambat sebagai akibat rendahnya jumlah maupun aktivitas mikroorganisme yang ada di dalamnya (Noor, 2001; Barchia, 2006), maka penambahan mikroorganisme terutama jamur dan bakteri yang menguntungkan tanaman perlu dilakukan (Worosuryani et al., 2006). Banyak bakteri rhizosfer yang mempunyai kemampuan sebagai pemacu pertumbuhan tanaman sekaligus mampu menekan perkembangan patogen dan dikenal sebagai rhizobakteria pemacu pertumbuhan atau Plant Growth Promoting Rhizobacteria (PGPR) (Hyakumachi \& Kubota, 2004). Beberapa kelompok pseudomonas berfluoresensi berperan membantu proses degradasi bahan organik dan sebagai bioreaktor untuk mengkatalisis pelarutan dan pelepasan fosfat dari partikel tanah (Wahyuni et al., 2005).

Pseudomonas berfluoresensi yang sudah banyak diteliti di Indonesia adalah Pseudomonas putida strain Pf-20, salah satu strain pseudomonas berfluoresensi hasil isolasi dari rhizosfer Mimosa invisa L. tanaman rotasi di areal perkebunan tembakau PTPN II, Sumatera Utara (Arwiyanto, 1997; Arwiyanto et al., 2003). P. putida strain Pf-20 mempunyai kemampuan yang tinggi sebagai antagonis terhadap Ralstonia solanacearum, meningkatkan produksi daun tembakau (Arwiyanto et al., 2003), mempunyai aktivitas yang tinggi dalam melarutkan fosfat, mempengaruhi total panjang dan kerapatan akar, juga mengurangi keparahan penyakit CMV pada tembakau (Wahyuni et al., 2005).

Selain PGPR, juga sudah dilaporkan bahwa jamur tanah mempunyai kemampuan yang sama. Beberapa jamur tanah seperti Trichoderma spp. dan Rhizoctonia spp. non patogenik dapat memacu pertumbuhan tanaman sebaik kemampuannya sebagai pengendali hayati. Jamur tersebut dikenal sebagai Plant Growth Promoting Fungi (PGPF) (Shivana et al., 1996). Isolat PGPF dari tanaman zoysiagrass (Zoysia tenuifolia Willd. Ex. Trin) diketahui dapat memacu pertumbuhan tanaman mentimun, tomat, lobak dan gandum. PGPF dapat memperbaiki pertumbuhan tanaman melalui mekanisme produksi hormon, membantu mineralisasi dan penekanan mikroorganisme yang merugikan tanaman (Hyakumachi \& Kubota, 2004). Penggunaan PGPF ini di tanah gambut diharapkan mampu mengatasi kendala kesuburan tanah dalam budidaya tanaman lidah buaya.

Tujuan penelitian ini adalah untuk mengetahui kompatibilitas antara dua jamur PGPF hasil isolasi dari tanah gambut dengan bakteri agensia hayati P. putida strain Pf-20 dalam pengendalian secara hayati penyakit busuk lunak lidah buaya di tanah gambut. Uji kompatibilitas perlu dilakukan mengingat kemampuan yang dimiliki oleh PGPR dan PGPF tersebut sangat prospektif sehingga kedua jenis mikroorganisme yang mempunyai kemampuan sebagai pemacu pertumbuhan tanaman tersebut dapat diaplikasikan secara bersamasama dengan harapan mampu mengendalikan penyakit busuk lunak sekaligus mampu memperbaiki pertumbuhan lidah buaya di tanah gambut.

\section{METODE PENELITIAN}

Penelitian dilaksanakan di Laboratorium Ilmu Penyakit Tumbuhan Klinik, Jurusan Perlindungan Tanaman dan Rumah Kaca, Fakultas Pertanian, Universitas Gadjah Mada Yogyakarta. Penelitian dilaksanakan mulai bulan Oktober 2008 sampai September 2009. 
Uji Antagonisme Pseudomonas putida strain Pf-20 terhadap bakteri Erwinia chrysanthemi secara In Vitro. Uji antagonisme P. putida strain Pf-20 (koleksi Laboratorium Bakteriologi Tumbuhan Fakultas Pertanian UGM, Yogyakarta) terhadap bakteri E. chrysanthemi (isolat BRJ02 dan BRJ03 hasil isolasi dari tanaman lidah buaya asal Rasau Jaya, Kabupaten Kuburaya, Kalimantan Barat, isolat BST03 dan BST 04 hasil isolasi dari lidah buaya asal Siantan, Kota Pontianak) dilakukan dengan mengikuti metode Arwiyanto (1997). P. putida strain Pf-20 ditumbuhkan pada medium King's B. Setelah masa inkubasi selama 24 jam pada suhu $30^{\circ} \mathrm{C}$ cawan Petri dibalik dan pada tutupnya dituangi $1 \mathrm{ml}$ kloroform. Dua jam kemudian cawan Petri dibalik kembali pada posisi semula dan pada permukaan medium dituang suspensi bakteri E. chrysanthemi sebanyak 0,2 $\mathrm{ml}$ dalam $4 \mathrm{ml}$ medium semisolid (0,6\% medium NA suhu $40-45^{\circ} \mathrm{C}$ ). Kultur kemudian diinkubasi pada suhu $30^{\circ} \mathrm{C}$ selama 24 jam dan diukur zona penghambatannya. Uji lanjut untuk mengetahui mekanisme penghambatan bakteri agensia hayati P. putida strain Pf-20 terhadap E. chrysanthemi dilakukan dengan menumbuhkan bakteri E. chrysanthemi yang ada pada zona bening ke dalam medium air pepton $0,5 \%$ pada suhu kamar selama tiga hari.

Uji Daya Hambat PGPF dan P. putida strain Pf-20 secara In Vitro. Uji Daya Hambat PGPF (jamur Aspergillus sp. SNTH003 dan Penicillium sp. SNTH001 hasil isolasi dari tanah gambut Kalimantan Barat) dan P. putida strain Pf-20 dilakukan dengan mengikuti metode Soesanto \& Termoshuizen (2004) yang dimodifikasi. Isolat $P$. putida strain $\mathrm{Pf}-20$ digoreskan pada medium PDA dengan jarak $1 \mathrm{~cm}$ dari tepi cawan Petri. Setelah diinkubasi pada suhu kamar selama 24 jam, inokulum PGPF (5 mm) diinokulasikan di tengah-tengah cawan Petri dan diinkubasikan pada tempat gelap selama 14 hari. Perlakuan diulang 3 kali. Diameter koloni PGPF diukur setiap hari selama 14 hari dan dihitung persentase penghambatannya. Uji Daya Hambat ini juga dilakukan pada medium King's B dengan metode yang sama dan diulang 3 kali. Sebagai kontrol, inokulum PGPF ditumbuhkan sendiri di tengah-tengah cawan Petri tanpa agensia hayati $P$. putida strain Pf-20.

\section{Uji In Planta di Rumah Kaca}

Penyiapan dan Inokulasi P. putida strain Pf-20. Bakteri P. putida strain Pf-20 ditumbuhkan pada agar miring media King's B. Selanjutnya perbanyakan dilakukan dengan menumbuhkannya dalam $250 \mathrm{ml}$ media King's B cair pada suhu kamar. Setelah 48 jam, media diukur kekeruhannya dengan spektrofotometer pada panjang gelombang $600 \mathrm{~nm}$ guna mengetahui nilai ODnya. Kerapatan $10^{8} \mathrm{cfu} \mathrm{ml}^{-1}$ didapatkan dengan mengencerkan medium berdasarkan persamaan yang diperoleh pada waktu penghitungan kerapatan bakteri.

Pengaruh P. putida strain Pf-20 terhadap Penyakit Busuk Lunak. Akar bibit lidah buaya, Aloe barbadensis Miller umur 4 bulan (berdaun 4, hasil kultur jaringan dari Aloe vera Center, Pontianak) direndam 15 menit dalam suspensi P. putida strain Pf- $20\left(10^{8} \mathrm{cfu}\right.$ $\mathrm{ml}^{-1}$ ) ditiriskan pada kertas saring dan ditanam pada pot berisi $250 \mathrm{~g}$ tanah gambut steril. Setelah tanaman lidah buaya berumur 21 hari setelah tanam (hst) diinokulasi dengan bakteri $E$. chrysanthemi dengan cara penyemprotan merata pada permukaan tanaman (kerapatan $6 \times 10^{6} \mathrm{cfu} \mathrm{ml}^{-1}$, volume $10 \mathrm{ml}$ per tanaman) yang sebelumnya telah dilukai menggunakan jarum steril. Tanaman diinkubasi di rumah kaca pada suhu kamar dan media dijaga dalam keadaan kapasitas lapang. Pengamatan dilakukan setiap minggu selama 9 minggu terhadap gejala penyakit yang muncul dengan cara skoring.

Pengaruh PGPF terhadap Penyakit Busuk Lunak. Bibit lidah buaya umur 4 bulan (berdaun 4 , hasil kultur jaringan) di tanam dalam pot berisi $250 \mathrm{~g}$ tanah gambut steril yang telah ditambahi dengan $5 \mathrm{~g}$ inokulum isolat PGPF dalam medium jagung steril (perbandingan 1:1 w/v jagung kering dan air). Tanaman diinkubasi di rumah kaca pada suhu kamar dan medium dijaga dalam keadaan kapasitas lapang. Setelah tanaman lidah buaya berumur 21 hst diinokulasi dengan bakteri E. chrysanthemi dengan cara penyemprotan merata pada permukaan tanaman (kerapatan $6 \times 10^{6} \mathrm{cfu} \mathrm{ml}^{-1}$, volume $10 \mathrm{ml}$ per tanaman) yang sebelumnya telah dilukai menggunakan jarum steril. Pengamatan dilakukan setiap minggu selama 9 minggu terhadap gejala penyakit yang muncul dengan cara skoring.

Pengaruh Aplikasi PGPF dan P. putida Pf-20 terhadap Penyakit Busuk Lunak. Tanaman lidah buaya umur 21 hst diinokulasi suspensi bakteri E. chrysanthemi dengan cara penyemprotan merata pada permukaan tanaman (kerapatan $6 \times 10^{6} \mathrm{cfu} \mathrm{ml}^{-1}$, volume $10 \mathrm{ml}$ per tanaman) yang sebelumnya telah dilukai menggunakan jarum steril. Sebelum tanam akar tanaman direndam 15 menit dalam suspensi $P$. putida Strain Pf-20 dan ditanam pada media tanam yang 
mengandung tanah gambut dan PGPF. Tanaman diinkubasi di rumah kaca pada suhu kamar dan medium dijaga dalam keadaan kapasitas lapang. Pengamatan dilakukan setiap minggu selama 9 minggu terhadap gejala penyakit yang muncul dengan cara skoring. Semua perlakuan pengujian disusun dalam rancangan acak lengkap dan diulang 5 kali.

Sebagai kontrol positif (tanpa pengendalian), tanaman lidah buaya umur 21 hst diinokulasi suspensi bakteri E. chrysanthemi dengan cara penyemprotan merata pada permukaan tanaman (kerapatan $6 \times 10^{6}$ cfu ml ${ }^{-1}$, volume $10 \mathrm{ml}$ per tanaman) yang sebelumnya telah dilukai menggunakan jarum steril dan sebelum tanam akar tanaman direndam dalam air destilasi steril lalu ditanam pada media taman yang mengandung tanah gambut tanpa PGPF. Sebagai kontrol negatif (tanpa inokulasi patogen), tanaman lidah buaya umur 21 hst diinokulasi air destilasi steril dengan cara penyemprotan merata pada permukaan tanaman (kerapatan $6 \times 10^{6}$ cfu ml-1, volume $10 \mathrm{ml}$ per tanaman) yang sebelumnya telah dilukai menggunakan jarum steril dan sebelum tanam akar tanaman direndam dalam air destilasi steril lalu ditanam pada media tanam yang mengandung tanah gambut tanpa PGPF.

Intensitas penyakit busuk lunak dihitung berdasarkan rumus berikut (Arwiyanto et al., 1994) :

$$
\mathrm{IP}=\frac{\sum_{\mathrm{i}}^{\mathrm{K}} \mathrm{k} \times \mathrm{nk}}{\mathrm{Z} \times \mathrm{N}} \times 100 \%
$$

IP $\quad=$ Intensitas Penyakit

$\mathrm{nk}=$ Jumlah tanaman dengan skor $\mathrm{k}(\mathrm{k}=0,1,2,3,4)$

$\mathrm{k}=$ Skor yang digunakan

$\mathrm{Z} \quad=$ Skor tertinggi

$\mathrm{N} \quad=$ Jumlah tanaman yang diamati

Skoring yang digunakan adalah: 0 = sehat, tanpa gejala; $1=1$ becak perpelepah, diameter becak kurang dari 1 $\mathrm{cm} ; 2$ = 1 becak melebar lebih dari $2 \mathrm{~cm}$, becak berubah warna dan tampak menjadi berair; $3=$ lebih dari 1 pelepah busuk; 4 = lebih dari 50\% bagian tanaman busuk.

\section{HASIL DAN PEMBAHASAN}

\section{Uji Antagonisme P. putida strain Pf-20 terhadap} E. Chrysanthemi secara In Vitro. Hasil yang didapatkan dalam pengujian ini adalah pada sekitar bekas koloni bakteri antagonis $P$. putida strain Pf-20 terjadi zona bening yang menunjukkan adanya zona penghambatan pertumbuhan bakteri E. chrysanthemi (Tabel 1). Hal ini menunjukkan bahwa bakteri agensia hayati $P$. putida strain Pf-20 mempunyai kemampuan menghambat pertumbuhan bakteri $E$. chrysanthemi secara in vitro.

Uji lanjut dengan menumbuhkan bakteri E. chrysanthemi yang ada pada zona bening ke dalam media cair berupa air pepton $0,5 \%$, memperlihatkan bahwa penghambatan tersebut hanya bersifat sementara karena setelah diinkubasikan ternyata medium air pepton berubah menjadi keruh kurang dari 48 jam setelah inokulasi. Menurut Arwiyanto (1997), medium air pepton yang menjadi keruh kurang dari 24 jam setelah diinkubasi dalam uji seperti ini dapat menunjukkan bahwa bakteri yang ditumbuhkan di dalamnya mampu tumbuh dengan cepat. Bakteri E. chrysanthemi yang diambil dari zona bening yang terbentuk diduga masih hidup dan ketika ditumbuhkan dalam media air pepton $0,5 \%$ bakteri tersebut kemudian tumbuh dengan cepat dan menyebabkan media menjadi keruh. Bakteri agensia hayati $P$. putida strain Pf-20 diketahui mampu menghasilkan senyawa antibiotik yang dapat menghambat pertumbuhan bakteri lainnya dengan mekanisme membunuh (sida) ataupun menghambat pertumbuhan (statik) (Arwiyanto, 1997). Berdasarkan hasil tersebut, diduga bakteri agensia hayati $P$. putida strain Pf-20 hanya bersifat bakteriostatik (menghambat tumbuh) bakteri E. chrysanthemi.

Uji Daya Hambat PGPF terhadap $P$. putida strain Pf-20 secara In Vitro. Uji Daya Hambat PGPF dan $P$. putida strain Pf-20 bertujuan untuk mengetahui pengaruh masing-masing PGPF terhadap pertumbuhan agensia hayati $P$. putida strain Pf-20 dan sebaliknya. Isolat jamur PGPF ditumbuhkan bersama dengan bakteri agensia hayati $P$. putida strain Pf-20 pada masing-masing medium berbeda, yaitu masing-masing berupa King's B dan PDA. Tabel 2 memperlihatkan bahwa dua jamur PGPF tersebut menunjukkan pertumbuhan yang berbeda ketika ditumbuhkan bersama-sama dengan $P$. putida strain Pf-20.

Hasil pengujian pada medium King's B menunjukkan bahwa, ketika ditumbuhkan bersama-sama dengan bakteri P. putida strain Pf-20, Aspergillus sp. isolat SNTH003 mampu tumbuh lebih baik jika dibandingkan dengan Penicillium sp. isolat SNTH001. Pertumbuhan yang lebih baik tersebut dapat dilihat dari lebih kecilnya perbedaan pertumbuhan koloni yang diamati dalam pengujian dibandingkan dengan kontrol yang ditunjukkan oleh nilai persentase hambatan yang lebih kecil. Jika ditumbuhkan hingga hari ke 14 inkubasi, 
Tabel 1. Rerata diameter zona hambatan yang terbentuk dalam uji antagonisme bakteri $P$. putida strain Pf-20 terhadap empat isolat bakteri E.chrysanthemi penyebab busuk lunak lidah buaya

\begin{tabular}{cc}
\hline Isolat $E$. chrysanthemi & Diameter zona hambatan $(\mathrm{cm})$ \\
\hline BRJ02 & $3,1 \mathrm{a}$ \\
BRJ03 & $3,0 \mathrm{a}$ \\
BST03 & $2,9 \mathrm{a}$ \\
BST04 & $2,8 \mathrm{a}$ \\
\hline
\end{tabular}

Keterangan: Huruf yang sama yang mengikuti angka dalam satu kolom yang sama menunjukkan tidak berbeda nyata dalam uji DMRT aras 5\%.

Tabel 2. Rerata diameter dua isolat jamur asal tanah gambut dalam Uji Daya Hambat dengan $P$. putida Strain Pf-20 pada dua jenis media

\begin{tabular}{|c|c|c|c|c|c|c|c|}
\hline \multirow{3}{*}{\multicolumn{2}{|c|}{ Isolat }} & \multicolumn{6}{|c|}{ Rerata diameter koloni (cm) dan persentase hambatan } \\
\hline & & \multicolumn{3}{|c|}{ Medium King’s B } & \multicolumn{3}{|c|}{ Medium PDA } \\
\hline & & Perlakuan & Kontrol & $\%$ hambatan & Perlakuan & Kontrol & $\%$ hambatan \\
\hline Aspergillus sp. & SNTH003 & 6,42 & 8,04 & 20,14 & 8,17 & 8,83 & 7,48 \\
\hline Penicillium sp. & SNTH001 & 2,32 & 6,17 & 62,40 & 4,77 & 7,27 & 34,39 \\
\hline
\end{tabular}

ujung koloni Aspergillus sp. tumbuh menyentuh tepi koloni P. putida strain Pf-20 meski tidak sampai melewatinya. Hal ini menunjukkan bahwa Aspergillus sp. bersifat lebih toleran terhadap antibiotik yang dihasilkan oleh bakteri $P$. putida strain Pf-20 dibandingkan dengan Penicillium sp. Pertumbuhan Penicillium sp. tampak sangat tertekan dengan keberadaan koloni P. putida strain Pf-20. Sampai hari ke-14 inkubasi, tepi koloni Penicillium sp. tidak dapat berkembang mendekati koloni P. putida strain Pf-20.

Demikian juga pada pertumbuhan di medium PDA, koloni bakteri $P$. putida strain Pf-20 berkembang tidak sebaik pada medium King's B, Aspergillus sp. isolat SNTH003 terlihat lebih toleran terhadap keberadaan P. putida strain Pf-20 dibandingkan dengan Penicillium sp. isolat SNTH001. Pengamatan pada hari ke-14 inkubasi, tampak tepi koloni Aspergillus sp. sudah mulai tumbuh di atas koloni P. putida strain Pf-20 meskipun terjadi gangguan pertumbuhan berupa kegagalan penebalan koloni. Miselium Penicillium sp. isolat SNTH001 tidak tumbuh mendekati koloni $P$. putida strain Pf-20 dan pertumbuhannya juga selalu menjauhi koloni P. putida strain Pf-20. Miselium Penicillium sp. pada bagian yang berhadapan dengan koloni $P$. putida strain Pf-20 mengeluarkan pigmen berwarna kemerahan yang terdifusi secara merata ke dalam media, bahkan sampai ke dalam beberapa bagian tertentu koloni $P$. putida strain Pf-20. Pigmen kemerahan ini belum diketahui peranannya dalam mempengaruhi pertumbuhan koloni $P$. putida strain Pf-20. Menurut Domsch et al. (1993), dalam kondisi lingkungan yang kurang menguntungkan untuk pertumbuhannya, beberapa anggota Penicilium sp. khususnya Penicilium purpurogenum mampu menghasilkan sejenis pigmen yang diduga merupakan salah satu senyawa yang ditujukan untuk mempertahankan diri. Kemungkinan, Penicillium sp. isolat SNTH001 menghasilkan pigmen berwarna kemerahan tersebut adalah sebagai tanggapan atas keberadaan koloni bakteri agensia hayati $P$. putida strain Pf-20 yang mampu menghasilkan senyawa yang bersifat antibiotik. Pigmen kemerahan tersebut diindikasikan adalah senyawa mitorubrinol seperti yang dinyatakan oleh Mapari et al. (2005), yang kemunculannya sangat tergantung kepada jenis medium tempat tumbuhnya.

Hasil pengujian ini menunjukkan bahwa Aspergillus sp. isolat SNTH003 lebih sesuai (lebih kompatibel) untuk digabungkan dengan $P$. putida strain Pf-20 dibandingkan dengan Penicillium sp. isolat SNTH001. 
Aplikasi Penggunaan PGPF dan P. putida Strain Pf20 in planta. Pengaruh penggunaan PGPF dan penggabungannya dengan $P$. putida strain Pf-20 terhadap penyakit busuk lunak lidah buaya diamati selama 9 minggu dimulai sejak minggu pertama setelah inokulasi E. chrysanthemi. Hasil pengamatan percobaan di rumah kaca yang dilakukan dengan cara skoring ditunjukkan pada Gambar 1. Gambar 1 menunjukkan bahwa pada akhir pengamatan, intensitas penyakit yang terjadi pada tanaman lidah buaya di rumah kaca bervariasi. Intensitas terendah terjadi pada tanaman lidah buaya yang diperlakukan dengan jamur PGPF Penicillium sp. isolat SNTH001 yaitu sebesar $25 \%$, kemudian bakteri agensia hayati $P$. putida strain Pf-20 dan kombinasinya dengan Penicillium sp. isolat SNTH001 sebesar masing-masing 40\%, Aspergillus sp. isolat SNTH003 45\% dan tanaman yang diperlakukan dengan kombinasi antara Aspergillus sp. isolat SNTH003 dan P. putida strain Pf-20 sebesar 70\%. Semua tanaman yang diperlakukan menunjukkan nilai intensitas penyakit yang lebih kecil dari pada tanaman yang tanpa pengendalian (kontrol positif) (Gambar 1).

Penurunan intensitas penyakit pada tanamantanaman yang dikendalikan tersebut dapat disebabkan oleh beberapa kemungkinan. Pertama, berhubungan dengan peningkatan pertumbuhan tanaman sehingga menjadi lebih baik (dibandingkan dengan yang sama sekali tidak dikendalikan) sebagai akibat dari pemacuan pertumbuhan tanaman oleh PGPF dan $P$. putida strain Pf-20. Kedua, berhubungan dengan senyawa-senyawa yang dihasilkan oleh PGPF maupun oleh bakteri agensia hayati $P$. putida strain Pf-20. Ketiga, juga ada kemungkinan karena meningkatnya ketahanan tanaman sebagai hasil pengimbasan ketahanan, baik yang dipicu oleh senyawa kimiawi yang dihasilkan PGPF dan agensia hayati $P$. putida strain Pf-20 tersebut maupun oleh interaksinya secara langsung dengan masing-masing agensia biologis tersebut.

Menggunakan analogi pada pengendalian penyakit busuk lunak pada tanaman kentang, pemberian agensia hayati berupa Pseudomonas fluoresens mampu mengurangi insidensi penyakit, memperbaiki pertumbuhan tanaman dan juga meningkatkan hasil umbi (Xu \& Gross, 1986; Kloepper et al., 2004). Menurut Hajhamed et al. (2007), pengendalian penyakit busuk lunak pada tanaman kentang, keberadaan senyawasenyawa yang secara tidak langsung memiliki peran antimikrobial memang dapat membantu meningkatkan ketahanan tanaman, atau setidaknya akan menurunkan gejala penyakit. Beberapa strain PGPF dari genus Trichoderma seperti $T$. virens mampu menginduksi produksi fitoaleksin pada tanaman dan juga mampu menghasilkan metabolit sekunder termasuk gliotoxin, gliovirin dan peptaibols yang bersifat antimikrobial (Pandya \& Saraf, 2010). Menurut Hyakumachi (2000), penggunaan PGPF dalam pengendalian hayati juga terbukti berimplikasi pada pengimbasan ketahanan secara sistemik sehingga dapat mengurangi gejala penyakit yang muncul pada bagian daun. Pengimbasan ketahanan tersebut sering bersifat persisten dan selalu berhubungan

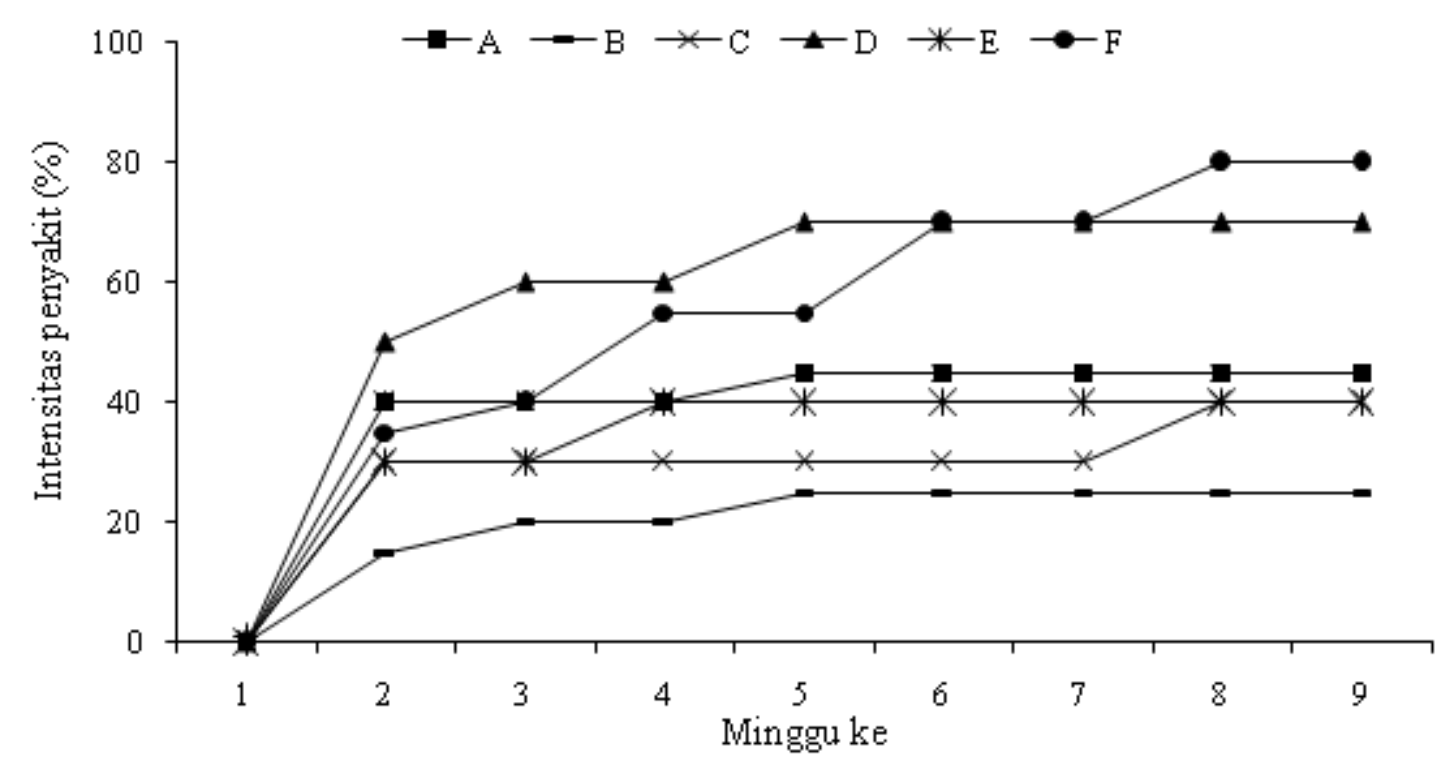

Gambar 1. Perkembangan intensitas penyakit busuk lunak lidah buaya selama 9 minggu pengamatan. A(Aspergillus sp.), B (Penicillium sp.), C (P. putida Strain Pf 20), D (Aspergillus sp.+ P. putida Strain Pf20), E (Penicillium sp.+ P. putida Strain Pf20), dan F (Tanpa pengendalian) 
dengan kemampuan mengkolonisasi perakaran tanaman (Meera et al., 1995).

Intensitas penyakit busuk lunak yang rendah pada tanaman yang dikendalikan dengan Penicillium sp., diduga selain karena pertumbuhan tanaman yang menjadi lebih baik akibat pemacuan pertumbuhan oleh PGPF, juga diduga karana adanya mekanisme induksi ketahanan tanaman lidah buaya yang terpicu oleh jamur tersebut. Menurut Pemberton et al. (2004), Erwinia chrysanthemi menyebabkan busuk lunak pada jaringan tanaman adalah karena kemampuannya mendegradasi pektat dan menurut Domsch et al. (1993), Penicilium purpurogenum juga mempunyai kemampuan mendegradasi pektat, sehingga dengan adanya dua kemampuan yang sama ini, ketika Penicillium sp. mengkoloni perakaran lidah buaya kemungkinan tanaman ini terpicu untuk menghasilkan senyawa pertahanan terhadap serangan patogen ini. Hal ini kemungkinan juga terjadi pada tanaman lidah buaya yang diberi perlakuan penggabungan Penicillium sp. dan $P$. putida strain Pf-20 di mana intensitas peyakitnya juga rendah. Hasil penelitian ini sama dengan hasil penelitian yang dilakukan oleh Chandanie et al. (2006), pemberian PGPF Penicillium simplicissimum telah membantu peningkatan ketahanan tanaman terhadap penyakit antraknosa yang disebabkan oleh Colletotrichum orbiculare. Mengenai dugaan peningkatan ketahanan yang menyebabkan penurunan intensitas penyakit tersebut, diperlukan penelitian lebih lanjut agar dapat dipastikan mekanismenya.

Pada tanaman lidah buaya yang diberi perlakuan jamur PGPF Aspergillus sp. intensitasnya lebih tinggi dibandingkan yang diperlakukan dengan Penicillium sp. tetapi lebih rendah dibandingkan dengan tanaman yang tidak dikendalikan. Hal ini diduga karena ketahanan tanaman juga meningkat tetapi peningkatan tersebut lebih disebabkan oleh pertumbuhan tanaman yang menjadi lebih baik sebagai efek pemacuan pertumbuhan oleh perannya sebagai PGPF. Peningkatan intensitas penyakit yang terjadi tampak mengikuti pola peningkatan pertumbuhannya, sehingga ketika peningkatan pertumbuhannya lebih rendah, peningkatan intensitas penyakitnya juga menjadi lebih tinggi (Tabel 3).

Pada tanaman lidah buaya yang diperlakukan dengan bakteri agensia hayati P. putida strain Pf-20, intensitas penyakit juga rendah, yaitu $30 \%$ hingga minggu ke-7 setelah inokulasi patogen dan kemudian meningkat menjadi $40 \%$ hingga akhir pengamatan. Mengingat pemberian agensia hayati $P$. putida strain Pf-20 tidak mampu memperbaiki pertumbuhan tanaman sebagaimana ditunjukkan oleh parameter-parameter pertumbuhannya (Tabel 3), rendahnya intensitas penyakit dibandingkan tanaman yang tidak dikendalikan diduga karena adanya mekanisme pengimbasan ketahanan oleh P. putida strain Pf-20. Menurut Kloepper et al. (1999), penggunaan bakteri agensia hayati terhadap patogen yang bersifat soil-borne juga berpotensi menginduksi ketahanan tanaman secara sistemik terhadap penyakit yang menyerang bagian daun. Dalam penelitian yang dilakukan oleh Wahyuni et al. (2005), penggunaan P. putida strain Pf-20 pada tanaman tembakau telah meningkatkan ketahanan tembakau terhadap Cucumber mosaic virus. Mekanisme induksi ketahanan seperti ini diduga berperan dalam membantu peningkatan ketahanan tanaman lidah buaya terhadap penyakit busuk lunak sehingga intensitas penyakitnya menjadi lebih rendah dibandingkan dengan tanpa pengendalian. Peningkatan intensitas penyakit pada minggu ketujuh kemungkinan berhubungan dengan kerapatan populasi dan kemampuan bertahan bakteri $P$. putida strain Pf-20 di lingkungan perakaran lidah buaya.

Membandingkan pertumbuhan tanaman antara yang diinokulasi patogen dengan yang tidak diinokulasi patogen, terlihat bahwa kecuali pemberian gabungan antara Aspergillus sp. dan P. putida strain Pf-20, pemberian perlakuan Aspergillus sp., Penicillium sp., $P$. putida strain Pf-20, dan gabungan antara Penicillium sp. dengan $P$. putida strain Pf-20 mampu secara nyata mempertahankan jumlah daun dibandingkan dengan tanaman yang tanpa pengendalian. Berdasarkan parameter pertambahan tinggi tanaman, hanya perlakuan pemberian jamur Penicillium sp., $P$. putida strain Pf-20 dan gabungan antara Penicillium sp. dengan $P$. putida strain Pf-20 yang tetap mampu mempertahankan tinggi tanaman sama dengan tanaman yang tidak diinokulasi patogen.

Berdasarkan parameter panjang dan bobot segar akar, hanya perlakuan pemberian PGPF Penicillium sp. dan kombinasinya dengan $P$. putida strain Pf-20 yang mampu mempertahankan panjang dan bobot segar akar sebagaimana tanpa keberadaan patogen (Gambar 2). Adapun berdasarkan pertambahan bobot segar tanaman, hanya perlakuan pemberian Penicillium sp. dan bakteri agensia hayati $P$. putida strain Pf-20 yang mampu mempertahankan pertambahan bobot segar brangkasan dibanding jika tanpa keberadaan patogen E. chrysanthemi (Gambar 3).

Hasil ini mengindikasikan bahwa pemberian jamur Penicillium sp. lebih efektif dibanding perlakuan lainnya dalam menurunkan intensitas penyakit busuk lunak pada tanaman lidah buaya pada tanah gambut di rumah kaca. Pemberian bakteri agensia hayati $P$. putida strain 
Tabel 3. Rerata beberapa parameter pertumbuhan tanaman lidah buaya dalam uji penggunaan PGPF dan $P$. putida strain Pf-20 pada umur 12 minggu setelah tanam

\begin{tabular}{|c|c|c|c|c|c|c|}
\hline \multirow[b]{2}{*}{ Perlakuan } & \multicolumn{5}{|c|}{ Parameter Pertumbuhan } & \multirow[b]{2}{*}{$\begin{array}{c}\text { Intensitas } \\
\text { penyakit (\%) }\end{array}$} \\
\hline & $\begin{array}{c}\text { Jumlah } \\
\text { daun total }\end{array}$ & $\begin{array}{l}\text { Pertambahan } \\
\text { tinggi tanaman } \\
\text { (cm) }\end{array}$ & $\begin{array}{c}\text { Panjang } \\
\text { akar (cm) }\end{array}$ & $\begin{array}{l}\text { Bobot Segar } \\
\text { akar (g) }\end{array}$ & $\begin{array}{c}\text { Pertambahan } \\
\text { bobot segar } \\
\text { tanaman (g) }\end{array}$ & \\
\hline \multicolumn{7}{|c|}{ Tanpa inokulasi E. chrysanthemi } \\
\hline Aspergillus sp. & $8,0 \mathrm{~d}$ & $8,5 \mathrm{c}$ & $22,0 \mathrm{c}$ & $3,0 \mathrm{ab}$ & 95,5 c & 0 \\
\hline Penicillium sp. & $7,2 \mathrm{~cd}$ & 7,6 bc & 19,8 bc & $3,4 \mathrm{ab}$ & 100,9 c & 0 \\
\hline P. putida strain Pf-20 & $6,4 \mathrm{~cd}$ & $4,3 \mathrm{ab}$ & $16,6 \mathrm{abc}$ & $3,6 \mathrm{~b}$ & 78,5 bc & 0 \\
\hline $\begin{array}{l}\text { Aspergillus sp. }+ \\
\text { P. putida strain Pf-20 }\end{array}$ & $7,4 \mathrm{~cd}$ & $6,3 \mathrm{abc}$ & 17,4 bc & $2,6 \mathrm{ab}$ & 86,3 c & 0 \\
\hline $\begin{array}{l}\text { Penicillium sp. }+ \\
\text { P. putida strain Pf-20 }\end{array}$ & $7,6 \mathrm{~d}$ & 7,9 bc & 20,8 c & $2,4 \mathrm{ab}$ & $87,1 \mathrm{c}$ & 0 \\
\hline $\begin{array}{l}\text { Tanpa PGPF dan } \\
\text { P. putida Strain Pf-20 }\end{array}$ & $7,0 \mathrm{~cd}$ & $5,7 \mathrm{abc}$ & $17,2 \mathrm{abc}$ & $3,3 \mathrm{~b}$ & 82,4 bc & 0 \\
\hline \multicolumn{7}{|c|}{ Dengan inokulasi E. chrysanthemi } \\
\hline Aspergillus sp. & 5,6 bc & $4,6 \mathrm{ab}$ & $16,2 \mathrm{abc}$ & $3,0 \mathrm{ab}$ & $71,4 \mathrm{abc}$ & 45 \\
\hline Penicillium sp. & $7,4 \mathrm{~cd}$ & 7,5 bc & 22,2 c & 3,7 b & 105,9 c & 25 \\
\hline P. putida strain Pf-20 & $7,0 \mathrm{~cd}$ & $5,5 \mathrm{abc}$ & $13,8 \mathrm{ab}$ & $2,4 a b$ & 78,6 bc & 40 \\
\hline $\begin{array}{l}\text { Aspergillus sp. }{ }^{+} \\
\text {P. putida strain Pf-20 }\end{array}$ & $4,2 \mathrm{ab}$ & 3,6 a & $1 \quad 7,7$ abc & $1,5 \mathrm{a}$ & $36,7 \mathrm{ab}$ & 70 \\
\hline $\begin{array}{l}\text { Penicillium sp. }{ }^{+} \\
\text {P. putida strain Pf-20 }\end{array}$ & $6,8 \mathrm{~cd}$ & $5,2 \mathrm{abc}$ & 20,0 bc & $2,4 \mathrm{ab}$ & 74,8 abc & 40 \\
\hline $\begin{array}{l}\text { Tanpa PGPF dan } \\
\text { P. putida Strain Pf-20 }\end{array}$ & 3,4 a & 2,3a & $13,0 a$ & $1,5 \mathrm{a}$ & 31,6 a & 80 \\
\hline
\end{tabular}

Keterangan: Huruf yang sama yang mengikuti angka dalam satu kolom yang sama menunjukkan tidak ada beda nyata dalam uji DMRT aras 5\%.

Pf-20 mampu menurunkan intensitas penyakit busuk lunak lidah buaya, tetapi tidak mampu membantu memperbaiki pertumbuhan tanaman lidah buaya dibandingkan dengan tanaman yang tidak diberi PGPF dan gabungannya dengan bakteri agensia hayati $P$. putida strain Pf-20. Pemberian PGPF Aspergillus sp. mampu meningkatkan pertumbuhan lidah buaya tetapi kurang mampu mempertahankan pertumbuhannnya ketika diinokulasi bakteri patogen E. chrysanthemi.

\section{SIMPULAN}

Pemberian dua isolat PGPF dan bakteri P. putida strain Pf-20 dalam penelitian ini mampu menurunkan intensitas penyakit busuk lunak lidah buaya. Penurunan intensitas penyakit terendah diperoleh dari perlakuan pemberian isolat Penicillium sp. SNTH001 yaitu sebesar 25\%, diikuti pemberian bakteri agensia hayati P. putida strain Pf-20 dan kombinasinya dengan Penicillium sp. SNTH001 sebesar masing-masing 40\%, Aspergillus sp. SNTH003 45\% dan tanaman yang diperlakukan dengan kombinasi antara Aspergillus sp. SNTH003 dan P. putida strain Pf-20 sebesar 70\%. Pemberian isolat Penicillium sp. SNTH001, mampu mempertahankan jumlah total daun, tinggi tanaman, panjang dan bobot segar akar serta bobot segar tanaman hampir sama dengan tanaman yang tidak diinokulasi patogen. Selain itu, pemberian dua isolat PGPF secara tunggal dapat membantu pertumbuhan lidah buaya, tetapi penggabungannya dengan $P$. putida strain Pf-20 tidak dapat meningkatkan pengaruhnya dalam memperbaiki pertumbuhan tanaman, sedangkan pemberian bakteri agensia hayati $P$. putida strain Pf-20 tidak dapat membantu memperbaiki pertumbuhan tanaman lidah buaya. 


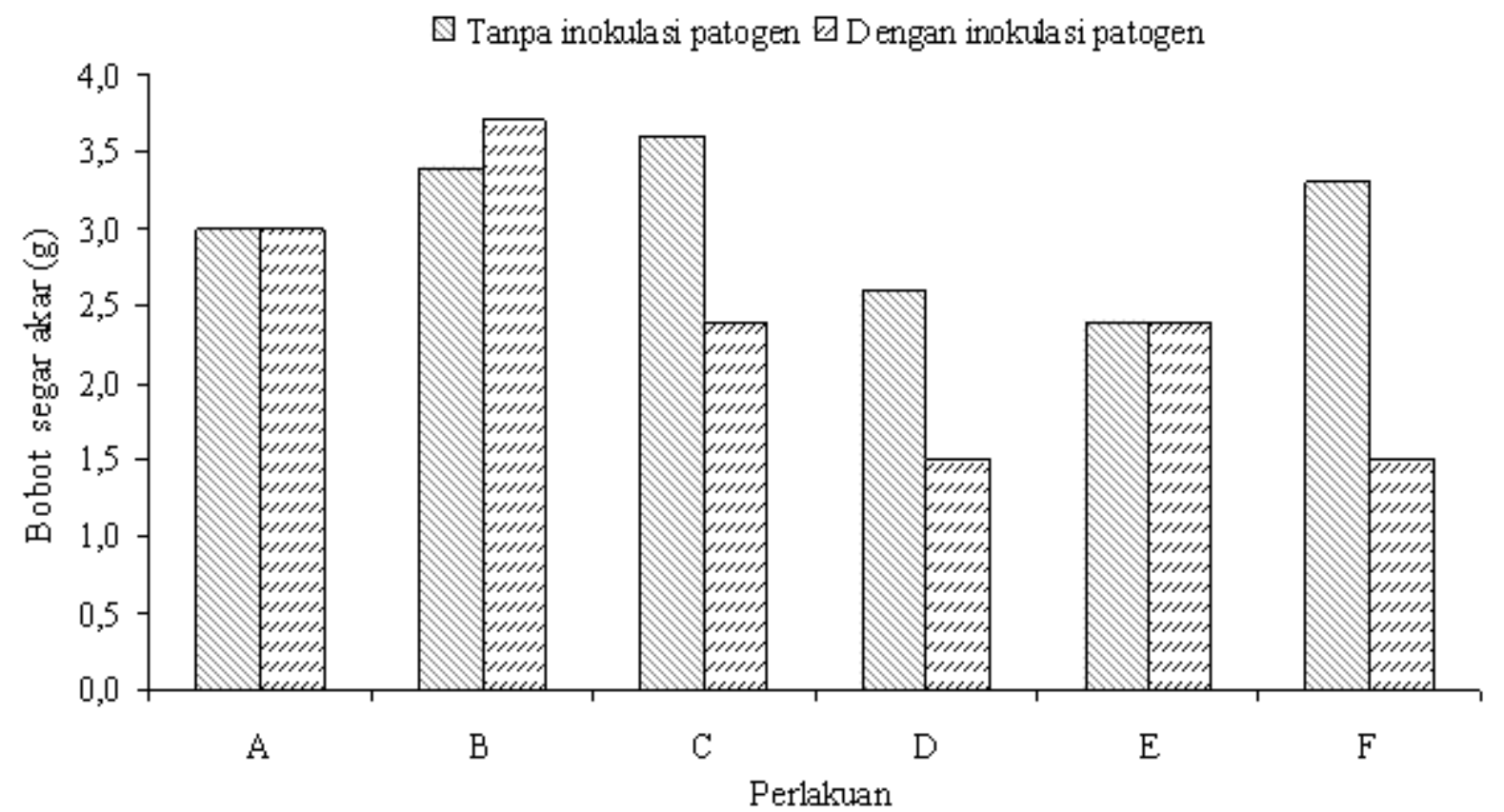

Gambar 2. Rerata bobot akar lidah buaya pada berbagai perlakuan. A (Aspergillus sp.), B (Penicillium sp.), C ( $P$. putida Strain Pf 20), D (Aspergillus sp.+ P.putida Strain Pf20), E (Penicillium sp. sp.+ P.putida Strain Pf20), dan F (Tanpa PGPF dan P. putida Strain Pf-20)

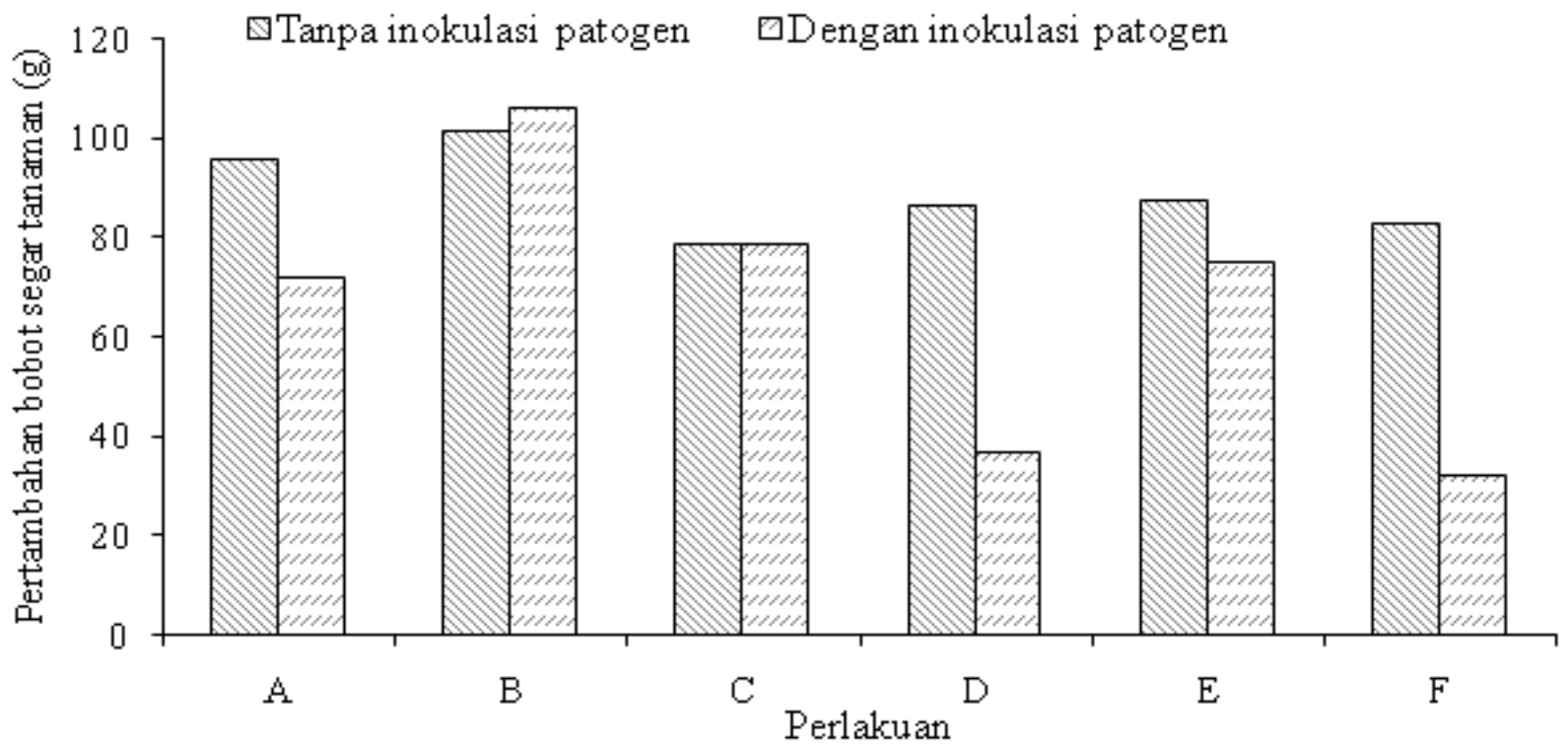

Gambar 3. Rerata pertambahan bobot segar lidah buaya pada berbagai perlakuan. A (Aspergillus sp.), B (Penicillium sp.), C (P. putida Strain Pf 20), D (Aspergillus sp.+ P.putida Strain Pf20), E (Penicillium sp. sp.+ P.putida Strain Pf20), dan F (Tanpa PGPF dan P. putida Strain Pf-20) 


\section{DAFTAR PUSTAKA}

Aisyah S. 2005. Manfaat Lidah Buaya (Aloe vera Linn.). Jurnal Aloe Vera IV: 1-6.

Aminardi, Yudiono S \& Ismayana E. 2006. Respon Petani Aloe vera terhadap Keberadaan Pabrik Pengolahan Aloe vera PT Niramas Utama di Kecamatan Pontianak Utara. J. Aloe Vera IV: $17-27$.

Anonim. 2008. Pengembangan Prasarana dan Sarana Desa Agropolitan Propinsi Kalimantan Barat. Kawasan Agropolitan Kota Pontianak. Profil Kalbar. http://www.pu.go.id/ditjen_mukim/ agro/profil_kws/PROFIL\%20KALBAR.PDF. Diakses tanggal 26 Oktober 2008.

Arwiyanto T, Goto M, Tsuyumu S \& Takikawa Y. 1994. Biological control of tomato bacterial wilt with the use of avirulent strain of Pseudomonas solanacearum isolated from Sterilitzia reginae. Annual Phytopathology Society Japan 60: 421430.

Arwiyanto T. 1997. Pengendalian Hayati Penyakit Layu Bakteri tembakau: 1. Isolasi Bakteri Antagonis. Jurnal Perlindungan Tanaman Indonesia 3: 44-60.

Arwiyanto T, Martoredjo T \& Hartana I. 2003. Pembuatan Formulasi Pestisida Hayati Untuk Pengendalian Penyakit Layu Bakteri Tembakau. Laporan Komprehensif Penelitian Hibah Bersaing IX Perguruan Tinggi Fakultas Pertanian UGM. Tidak dipublikasikan.

Balai Pengkajian Bioteknologi BPPT \& Pemerintah Kota Pontianak. 2001. Kerangka Acuan Pengembangan Pusat Pengkajian dan Pengembangan Aloe vera (Aloe Center) Kota Pontianak.

Barchia MF. 2006. Gambut, Agroekosistem dan Transformasi Karbon. Gadjah Mada University Press, Yogyakarta.

Chandanie WA, Kubota M \& Hyakumachi M. 2006. Interactions between Plant Growth Promoting Fungi and Arbuscular Mycorrhizal Fungus Glomus mosseae and induction of systemic resistance to anthracnose disease in cucumber. Plant and Soil 286: 209-217.

Charkowski AO. 2007. The soft rot Erwinia. Pp. 423505 In: Gnanamanikam SS. Plant Assosiated Bacteria. Springer, Dordreht.

De Laat PCA, Verhoeven JTW \& Janse JD. 1994. Bacterial leaf rot of Aloe vera L. caused by Erwinia chrysanthemi Biovar 3. European Journal of Plant Pathology 100: 81-84.

Dinas Pertanian Propinsi Kalimantan Barat. 2001. Mutiara Hijau yang Menjanjikan. Sub Dinas Bina Produksi Hortikultura.

Domsch KH, Gams W \& Anderson TH. 1993. Compendium of Soil Fungi, Volume I. Verlag.

Hajhamed AA, Wafaa M, Abd El-Sayed, Abou ElYazied A \& Abd El-Ghaffar NY. 2007. Suppression of bacterial soft rot disease of potato. Egypt. J. Phytopathol 35(2): 69-80.

Hyakumachi M. 2000. Studies on biological control of soilborne plant pathogens. Journal of Gen. Plant Pathol. 66: 272-274.

Hyakumachi M \& Kubota M. 2004. Fungi as Plant Growth Promoter and Disease Suppressor. Pp. 101-110 In: Arora DK. Fungal Biotechnology in Agriculture, Food, and Environmental Applications. Marcel Dekker Inc. Lousiana.

Kusnandar D, Suyatno A \& Trisiana F. 2006. Studi Komparatif Pembiayaan dan Pendapatan Usahatani Pepaya dan Lidah Buaya di Kecamatan Pontianak Utara. J. Aloe Vera VI: $1-10$.

Kloepper JW, Rodrigues-Ubana R, Zehnder GW, Murphy JF, Shikora E \& Fernandez C. 1999. Plant Root-bacterial interactions in biological control of soilborne diseases and potential extension to systemic and foliar diseases. Australasian Plant Pathology 28: 21-26.

Kloepper JW, Ryu CM \& Zhang S. 2004. Induced systemic resistance and promotion of plant growth by Bacillus spp. Phytopathology 94: 1259-1266. 
Mandal K \& Maiti S. 2005. Bacterial soft rot of Aloe caused by Pectobacterium chrysanthemi: a new report from India. Plant Pathology 54: 573-573.

Mapari SAS, Nielsen KF, Larsen TO, Frisvad JC, Meyer AS \& Thrane U. 2005. Exploring Fungal Biodiversity for the Production of Water-soluble Pigments as Potential Natural Food Colorants. Current Opinion in Biotechnology 16:231-238.

Meera MS, Shivanna MB, Kageyama K \& Hyakumachi M. 1995. Persistence of induced systemic resistance in cucumber in relation to root colonization by plant growth promoting fungal isolates. Crop Protection 14: 12-130.

Noor M. 2001. Pertanian Lahan Gambut. Penerbit Kanisius, Yogyakarta.

Pandya U \& Saraf M. 2010. Application of Fungi as a biocontrol agent and their biofertilizer potential in agriculture. Journal of Adv. Dev. Res.1: 90-99.

Pemberton CL, Slater H \& Salmond GPC. 2004. Chemical signalling by Bacterial Plant Pathogens. Pp. 133-135 In: Gilling M \& Holmes A. Plant Microbiology. Garland Science, Abingdon.

Rianto F \& Sarbino. 2004. Pengendalian Penyakit Busuk Lunak Pada Lidah Buaya (Aloe vera) Secara Non Kimiawi Dengan Memanfaatkan Mikroorganisme Antagonis. Jurnal Aloe Vera III: 23-28.
Shivana MB, Meera MS, Kageyama K \& Hyakumachi M. 1996. Growth Promotion Ability of Zoysiagrass Rhizosphere Fungi in Consecutive of Wheat and Soybean. Mycoscience 37: 163168.

Soesanto L \& Thermoshuizen AJ. 2004. Pengendalian Hayati Verticillium dahliae pada Arabidopsis thaliana dan Terung dengan Penggabungan Pseudomonas fluorescens dan Talaromyces flavus. Jurnal Agroland 11: 1-10.

Suswati D, Umran I \& Sukmawati T. 2005. Pengaruh Kombinasi Pukan Ayam dan Pupuk Fosfor Terhadap Serapan P dan Pertumbuhan Tanaman Lidah Buaya Pada Tanah Gambut. Jurnal Aloe Vera VII: 11-21.

Wahyuni WS, Iwan A, Mudjiharjati A, Setyowati TC \& Purwiko H. 2005. Kemampuan Pseudomonas putida Pf-20 dan 24.7B untuk Memperbaiki Sifat Kimia Media Tumbuh dan Ketahanan Terinduksi Tembakau H877 terhadap Cucumber mosaic virus. Jurnal Perlindungan Tanaman Indonesia 11: 77-87.

Worosuryani C, Priyatmojo A \& Wibowo A. 2006. Uji Kemampuan Jamur yang diisolasi dari Lahan Pasir sebagai PGPF (Plant Growth Promoting Fungi). Jurnal Agrosains 19: 179-192.

Xu GW \& Gross DC. 1986. Field evaluation of the interactions among fluorescent pseudomonads and Erwinia carotovora and potato yields. Phytopathology 76: 423-430. 